\title{
Synthesis and Characterization of new metals complexes of [N-(4- chlorobenzoylamino)-thioxomethyl]valine (cbv)
}

\author{
Muhammed A. Al-Krboly*, Basima M. Sarhan**, Abdullah Sh. Alany* \\ *-Department of chemistry, Collage of Education for pure sciences ,University of Al-anbar \\ **- Department of chemistry, Collage of Education for pure sciences, Ibn-Al-hatham, University of Baghdad
}

\begin{abstract}
A new ligand [N-(4-chlorobenzoyl amino) -thioxomethyl] valine (cbv) is synthesized by reaction of 4chloro benzoyl iso thio cyanate with valine acid. The ligand is Characterized by elemental analysis, FT-IR, and ${ }^{13} C^{1} H$ NMR spectra, some transition metals complex of this ligand were prepared and Characterized by FTIR , UV-Visible spectra, conductivity measurement's ,magnetic susceptibility, atomic absorption and determination of molar ratio $(M: L)$, from results obtained, the following formula $\left[M(c b v)_{2}\right]$ where $M^{+2}=M n$, $\mathrm{Fe}, \mathrm{Co}, \mathrm{Ni}, \mathrm{Cu}, \mathrm{Zn}, \mathrm{Cd}$, and $\mathrm{Hg}$ and the proposed molecular structure for these complexes as tetrahedral geometry, except copper complex is have square planer geometry .

Key word : Valine, 4-chloro benzoyl isothiocyanate, transition metal .
\end{abstract}

\section{Introduction}

The metal complexes derived from amino acid and their derivatives have important pharmaceuticals applications, they have been exploited in cancer multi drugs resistance ${ }^{(1)}$ tested as anti-material ${ }^{(2)}$ and exhibit anti-tumor activity ${ }^{(3)}$,also thiourea derivatives have several important use in medicines as potent anti-cancer and anti-influenza agents ${ }^{(4,5)}$, Ranjana S. and Coworkers ${ }^{(6)}$ were reported the synthesis and characterization of $\mathrm{N}$-salicylidine amino acids (lycine ,leucine) with some bivalent transition metal ions . R. Selwien and Coworkers $^{(7)}$ reported the synthesis, characterization and biological studies of some metal ions complexes derived from indol 3-caboxaldclyde and glycgly as Schiff base ligand and a new series ${ }^{(8)}$ of amino acid derivatives and it's metal complex based on $\mathrm{N}$-[3,5-dinitrobenzoylamino-selenomethly]amino acids (HL) where $\mathrm{HL}$ : alanine and glycine were synthesized and characterized and all ligand were showed biological activity the aim of this work preparation some transition metal complexes of [N-(4-chlorobenzoylamino) thioxomethyl]valine .

\section{Experimental}

All regents used were annular or chemically pure grade by British drug house (BHD), Merk and Fluka. Metal salts $\left(\mathrm{CoCl}_{2} \cdot 6 \mathrm{H}_{2} \mathrm{O}, \mathrm{NiCl}_{2} \cdot 6 \mathrm{H}_{2} \mathrm{O}, \mathrm{CuCl}_{2} \cdot 2 \mathrm{H}_{2} \mathrm{O}, \mathrm{ZnCl}_{2}, \mathrm{CdCl}_{2} \cdot \mathrm{H}_{2} \mathrm{O}, \mathrm{HgCl}_{2}, \mathrm{MnCl}_{2} .4 \mathrm{H}_{2} \mathrm{O}, \mathrm{FeCl}_{2}\right)$ valine , ammonium thio cyanate ,4-chloro benzoyl chloride, acteon, di methyl sulphoxide, ethanol .

Instrument :

${ }^{13} \mathrm{C},{ }^{1} \mathrm{H}$ NMR were recorded by using ultra shield $300 \mathrm{MHz}$ Switzerland at university of Al Al-bayt, Jordan. Conductivity measurement were carried out using Philips PW digital meter conductivity in DSMO at $10^{-}$ ${ }^{3} \mathrm{M}$, FT-IR spectra were recorded as $\mathrm{KBr}$ discs in the range $(4000-400) \mathrm{cm}^{-1}$ using Shimadzu FT-IR ,UVVisible spectra were recorded by Shimadzu UV-8300 Vis 160 A ultra-violate spectra photometer at the range of (200-1100) $\mathrm{nm}$ at $10^{-3} \mathrm{M}$ in DMSO , metal contents of the complexes were determined by atomic absorption using( Shimadzu a a 6806) atomic absorption spectra photometer, magnetic susceptibility ( $\mu$ eff, B.M) were recorded by farada method using balance magnetic susceptibility model MSB -MKI . melting point were determined by using (suture melting point apparatus ), element analysis (C.H.N.S)were preformed using a Carlo Erba 1106 elemental analyzer .

Synthesis of the ligand (cbv)

\section{1-preparation of 4-chlorobenzoyl-iso thio cyanate:}

Mixture of 4-chloro benzoyl chloride $(3.34 \mathrm{ml}),(1 \mathrm{mmol})$ and ammonium thiocyanate $(2 \mathrm{~g}),(1 \mathrm{mmol})$ in $(25$ $\mathrm{ml})$ of acetone was stirred under refluxed for 3 hours and then filtered, the filtrate was used for further reaction (9).

2-preparation of [N-(4-chlorobenzoyl amino)thioxomethyl]valine (cbv)

$(3.08 \mathrm{~g}),(1 \mathrm{mmol})$ of valine in $(20 \mathrm{ml})$ acetone was rapidly added to the above solution to maintain vigorous reflux . after refluxing for 6 hours, the resulting solid was collected, washed with acetone and recrystallization from ethanol. scheme (1)

Yield (\%86), M.P. $(153-155)^{\circ} \mathrm{C}$ 
\%C Found (50.007), While calculate $(49.60), \% \mathrm{H}$ found (5.008) while calculate (4.76), \% $\mathrm{N}$ found (8.56) while calculate (8.90) and \%S found (10.09) while calculate (10.17) .
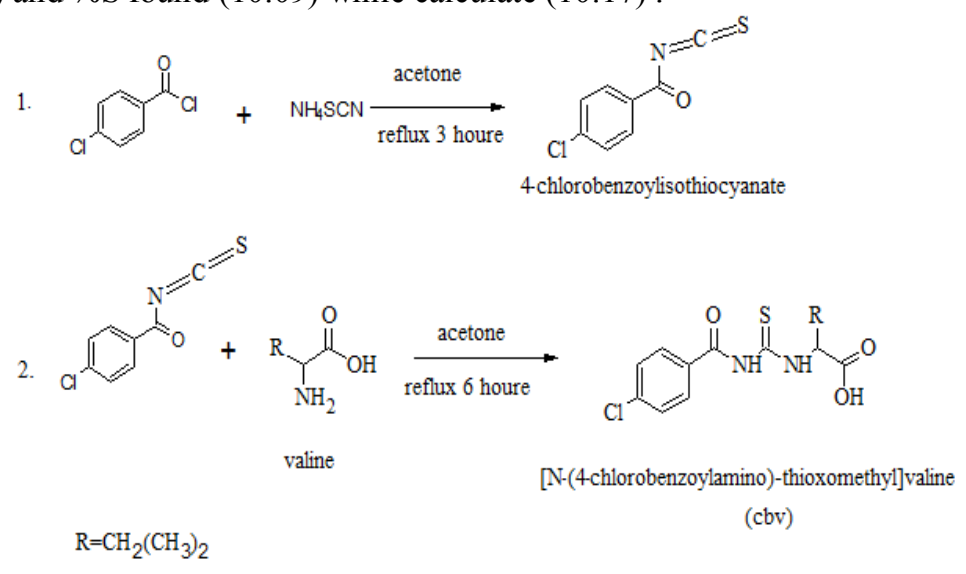

$$
\begin{aligned}
& \text { scheme(1) preparation of } \\
& \text { [N-(4-chlorobenzoylamino)-thioxomethyl]valine }
\end{aligned}
$$

Scheme (1) preparation of [N-(4chlorobenzoylamino)-thioxomethyl]valine

Synthesis of complexes :

$(0.628 \mathrm{~g}, 2 \mathrm{mmol})$ of the ligand (cbv) was dissolved in $(25 \mathrm{ml})$ of ethanol containing $(0.12 \mathrm{~g}, 2 \mathrm{mmol})$ of $\mathrm{KOH}$ ,then the solution of (1mmol) of metal salt $\mathrm{MnCl}_{2} .4 \mathrm{H}_{2} \mathrm{O}, \mathrm{FeCl}_{2}, \mathrm{CoCl}_{2} .6 \mathrm{H}_{2} \mathrm{O}, \mathrm{NiCl}_{2} .6 \mathrm{H}_{2} \mathrm{O}, \mathrm{CuCl}_{2} .2 \mathrm{H}_{2} \mathrm{O}$, $\mathrm{ZnCl}, \mathrm{CdCl}_{2} . \mathrm{H}_{2} \mathrm{O}$ and $\mathrm{HgCl}_{2}(0.2 \mathrm{~g}, 0.13 \mathrm{~g}, 0.24 \mathrm{~g}, 0.24 \mathrm{~g}, 0.2 \mathrm{~g}, 0.14 \mathrm{~g}, 0.2 \mathrm{~g}$ and $0.3 \mathrm{~g}$ )respectively in ethanol $\mathrm{R}=\mathrm{CH}\left(\mathrm{CH}_{3}\right)_{2}$ ise to the solution of ligand (cbv) ${ }^{-} \mathrm{K}^{+}$. the precipitate formed immediately, after stirring the dried . emperature for (2)hours, the precipitate was collected by filtration, washed with ethanol and

III. Results and discussion :

The solid complexes ,soluble in some common solvent suck as dimethyl formamide ,dimethylsulphoxide, and relatively thermally stable the molar conductivity of all complexes in DMSO were found to be nonelectrolyte, table (1) includes the physical properties for the ligand and it's complexes . Spectral studies :

\section{${ }^{13} \mathrm{C},{ }^{1} \mathrm{H}$ NMR spectra:}

1- ${ }^{1} \mathrm{H}$ NMR spectra for the ligand (cbv) ( in $\mathrm{CDCl}_{3}+(1-2)$ drops DMSO as a solvent) of ligand (cbv) fig(1) showed the following signals : doublet at $\delta(1-1.2) \mathrm{ppm}$ for $\left(6 \mathrm{H}, 2 \mathrm{CH}_{3}\right)$, multiple at $\delta(1.41-2.48) \mathrm{ppm}$ for $\left(1 \mathrm{H}, \mathrm{CH}\left(\mathrm{CH}_{3}\right)_{2}\right)$, singlet at $\delta(2.59-3.70) \mathrm{ppm}$ for the solvent (DMSO), doublet at $\delta(4.60-4.67) \mathrm{ppm}$ for $(1 \mathrm{H}, \mathrm{NH}$ sec. amine), triplet at $\delta(4.97-5.01) \mathrm{ppm}$ for $(1 \mathrm{HCHCOOH})$, singlet at $\delta(7.20) \mathrm{ppm}$ for the solvent $\left(\mathrm{CDCl}_{3}\right)$,two doublet pairs at $\delta(7.38-7.91) \mathrm{ppm}$ for $(4 \mathrm{H}$,aromatic), singlet at $\delta(9.98) \mathrm{ppm}$ for $(1 \mathrm{H}, \mathrm{NH}$ sec. amide), singlet at $\delta(11.25) \mathrm{ppm}$ for $(1 \mathrm{H}, \mathrm{COOH})^{(10)}$.

2- The ${ }^{13} \mathrm{C}$ NMR spectrum (in $\mathrm{CDCl}_{3}+(1-2)$ drops DMSO as a solvent) of ligand (cbv) fig(2) showed the following signals : : singlet at $\delta(18.16-18.79) \mathrm{ppm}$ for $\left(2 \mathrm{CH}_{3}\right)$, singlet at $\delta(30.67) \mathrm{ppm}$ for $\left(\mathrm{CH}\left(\mathrm{CH}_{3}\right)_{2}\right)$, singlet at $\delta(39.62-40.18) \mathrm{ppm}$ for the solvent (DMSO), singlet at $\delta(63.32) \mathrm{ppm}$ for $(\mathrm{CHCOOH})$, singlet at $\delta(76.81$ 77.66)ppm for the solvent $\left(\mathrm{CDCl}_{3}\right)$, singlet at $\delta(128.53-139.64) \mathrm{ppm}$ for (C) aromatic , singlet at $\delta(166.43) \mathrm{ppm}$ for $(\mathrm{C}=\mathrm{O}$ sec. amide), singlet at $\delta(172.17) \mathrm{ppm}$ for $(\mathrm{COOH})$,singlet at $\delta(180.47) \mathrm{ppm}$ for $(\mathrm{C}=\mathrm{S})$.

Infrared spectrum :

$\mathrm{Ft}-\mathrm{IR}$ spectrum of the free ligand (cbv) fig (3)

Showed bands due to amidov $(\mathrm{NH}+\mathrm{OH}), v(\mathrm{C}=\mathrm{O})$ and $v(\mathrm{C}=\mathrm{S})$ which absorbed at $(3174+3271) \mathrm{cm}^{-1},(1670) \mathrm{cm}^{-1}$ and (1263) $\mathrm{cm}^{-1}$ respectively, while another absorption band appeared at $(1710) \mathrm{cm}^{-1}$ could be explained as $v(\mathrm{COO})_{\text {asym }}{ }^{(11,12)}$ where the $v\left((\mathrm{OCO})_{\text {sym }}\right.$ was noticed at $(1400) \mathrm{cm}^{-1}$.

The FT-IR spectra of complexes :

These spectra exhibited marked difference between bands fig(4) belonging to the stretching vibration of $v(\mathrm{NH})$ of the amine group in the range between $(3463-3383) \mathrm{cm}^{-1}$ shifted higher frequencies by $(298-209) \mathrm{cm}^{-}$ ${ }^{1}$ suggesting the possibility of the coordination of ligand through the nitrogen atom at the amine group ${ }^{(13)}$. absorption assigned for $v(\mathrm{COO})_{\mathrm{sym}}$ was noticed at the range $(1552-1440) \mathrm{cm}^{-1}$ shifted to higher frequencies by $(152-40) \mathrm{cm}^{-1}$ while the band caused by $v(\mathrm{COO})_{\text {asym }}$ appeared between $(1595-1550) \mathrm{cm}^{-1}$ shifted to lower frequencies by (115-160) $\mathrm{cm}^{-1}$ which indicates to the coordination of the carboxylic group to the central ion ${ }^{(14)}$. The stretching vibration band $v(\mathrm{C}=\mathrm{O})$ and $v(\mathrm{C}=\mathrm{S})$ carbonyl group either show no change or very little in their frequencies $(1668-1593) \mathrm{cm}^{-1}$ and $(1282-1236) \mathrm{cm}^{-1}$ respectively there for indicating do not coordinate to the 
metal ion ${ }^{(15)}$.

metal-nitrogen and metal-oxygen bonds were confirmed by the presence of the stretching vibration of $v(\mathrm{M}-\mathrm{O})$ and $v(\mathrm{M}-\mathrm{N})$ around $(482-441) \mathrm{cm}^{-1}$ and $(433-416) \mathrm{cm}^{-1}$ respectively ,table $(2)$ describe the important bands and assignment for free ligand (cbv)and it's complexes .

\section{Electronic spectral :}

The UV-Visible of the ligand (cbv) and it's complexes recorded in table(3) the solution of the ligand (cbv) in $10^{-3} \mathrm{M}$ (DMSO) exhibited two peaks fig(5) at (35842) $\mathrm{cm}^{-1}$ and (20242) $\mathrm{cm}^{-1}$ which are attributed to $\pi \rightarrow$ $\pi^{*}$ and $\mathrm{n} \rightarrow \mathrm{n}^{*}$ transition respectively ${ }^{(16)}$.

\section{The spectra of complexes :}

$-\left[\mathrm{Mn}(\mathrm{cbv})_{2}\right] \mathrm{d}^{5}$ : the yellow complex of $\mathrm{Mn}(\mathrm{II})$ shows band at $(37313) \mathrm{cm}^{-1}$ which belongs to charge transfer and another bands at $(15576) \mathrm{cm}^{-1}$ and $(11834) \mathrm{cm}^{-1}$ which are caused by the electronic transfer ${ }^{6} \mathrm{~A}_{1} \rightarrow{ }^{4} \mathrm{~T}_{2}$ (G) and ${ }^{6} \mathrm{~A}_{1} \rightarrow{ }^{4} \mathrm{~T}_{1}(\mathrm{G})$ respectively ${ }^{(17)}$.

$-\left[\mathrm{Fe}(\mathrm{cbv})_{2}\right] \mathrm{d}^{6}$ : the spectrum of the red complex of $\mathrm{Fe}(\mathrm{II})$ show bands at $(34013) \mathrm{cm}^{-1}$ and $(11587) \mathrm{cm}^{-1}$ due to charge transfer $(\mathrm{C} . \mathrm{T})$ and ${ }^{5} \mathrm{E} \rightarrow{ }^{5} \mathrm{~T}_{2}$ respectively ${ }^{(18)}$.

$-\left[\mathrm{Co}(\mathrm{cbv})_{2}\right] \mathrm{d}^{7}$ : the spectrum of the green complex gave three bands at $(33333) \mathrm{cm}^{-1},(15060) \mathrm{cm}^{-1}$ and (11834) $\mathrm{cm}^{-1}$ attributed to ${ }^{4} \mathrm{~A}_{2} \rightarrow{ }^{4} \mathrm{~T}_{1}(\mathrm{p})$ mix with $(\mathrm{C} . \mathrm{T}),{ }^{4} \mathrm{~A}_{2} \rightarrow{ }^{4} \mathrm{~T}_{1}(\mathrm{~F})$ and ${ }^{4} \mathrm{~A}_{2} \rightarrow{ }^{4} \mathrm{~T}_{2}(\mathrm{~F})$ respectively and the rach interelectronic repulsion parameter $\left(\mathrm{B}^{-}\right)$was found to be $(859.4) \mathrm{cm}^{-1}$, from the relation $\beta=\mathrm{B}^{-} / \mathrm{Bo}$ was found to be equal (0.88). these parameter are accepted to $\mathrm{Co}(\mathrm{II})$ tetrahedral complex ${ }^{(19)}$.

$-\left[\mathrm{Ni}(\mathrm{cbv})_{2}\right] \mathrm{d}^{8}:$ the spectrum of brown complex of $\mathrm{Ni}(\mathrm{II})$ has revealed the following electronic transfers $(\mathrm{C} . \mathrm{T}),{ }^{3} \mathrm{~T}_{1(\mathrm{~F})} \rightarrow{ }^{3} \mathrm{~T}_{1(\mathrm{P})},{ }^{3} \mathrm{~T}_{1(\mathrm{~F})} \rightarrow{ }^{3} \mathrm{~A}_{2(\mathrm{~F})}$ and ${ }^{3} \mathrm{~T}_{1(\mathrm{~F})} \rightarrow{ }^{3} \mathrm{~T}_{2(\mathrm{~F})}$ transition at $(37037) \mathrm{cm}^{-1},(32894) \mathrm{cm}^{-1},(14925) \mathrm{cm}^{-1}$ and $(11286) \mathrm{cm}^{-1}$ respectively, the $\mathrm{B}^{-}$value found to be $(930.7) \mathrm{cm}^{-1}$ while $\beta$ was equal to $(0.89)$ these are the characteristics for tetrahedral complexes of $\mathrm{Ni}(\mathrm{II}){ }^{(20)}$.

$-\left[\mathrm{Cu}(\mathrm{cbv})_{2}\right] \mathrm{d}^{9}$ : the spectrum of green complex of $\mathrm{Cu}(\mathrm{II})$ shows two bands at $(36496) \mathrm{cm}^{-1}$ and $(11641) \mathrm{cm}^{-1}$ caused to (C.T) and ${ }^{2} \mathrm{~B}_{1(\mathrm{~g})} \rightarrow{ }^{2} \mathrm{~A}_{1(\mathrm{~g})}$ transition respectively ${ }^{(21)}$.

-The complexes of $\left[\mathrm{Zn}(\mathrm{cbv})_{2}\right],\left[\mathrm{Cd}(\mathrm{cbv})_{2}\right]$ and $\left[\mathrm{Hg}(\mathrm{cbv})_{2}\right]$ shows only charge transfer of $(\mathrm{M} \rightarrow \mathrm{L})$ in range (33670-37313) $\mathrm{cm}^{-1(22)}$. All transition with their assignments are summarized in table (3).

Study of complexes from action in solution :

Complexes of ligand (cbv) with metal ions were studied in solution using ethanol as solvent in order to determine $[\mathrm{M} / \mathrm{L}]$ ratio in complexes follow molar method ${ }^{(23)}$.

A series of solution were prepared having a constant concentration $\left(10^{-3} \mathrm{M}\right)$ of metal ion and ligand . The $[\mathrm{M} / \mathrm{L}]$ ratio determined from the relationship between the absorption of the absorbed light and the mole ratio of $[\mathrm{M} / \mathrm{L}]$. The results of complexes in ethanol suggest that the metal to ligand ratio was [1:2] for all complexes which were similar to that obtained from solid state study .

According to spectral data as well as those obtained from elemental analyses the chemical structure of the complexes may be suggested as tetrahedral for $\left[\mathrm{M}(\mathrm{cbv})_{2}\right]$ where $\mathrm{M}^{+2}=\left(\mathrm{Mn}^{+2}, \mathrm{Fe}^{+2}, \mathrm{Co}^{+2}, \mathrm{Ni}^{+2}, \mathrm{Zn}^{+2}, \mathrm{Cd}^{+2}\right.$ and $\mathrm{Hg}^{+2}$ ) Scheme (2), while copper complex has square planer.

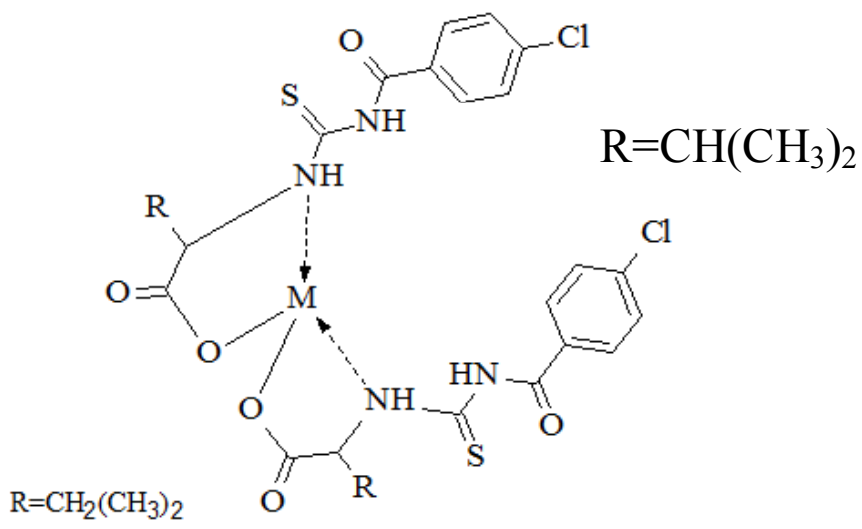

Scheme (2) tetrahedral complex of $\left[\mathrm{M}(\mathrm{cbv})_{2}\right]$ where $\mathrm{M}^{+2}=\left(\mathrm{Mn}^{+2}, \mathrm{Fe}^{+2}, \mathrm{Co}^{+2}, \mathrm{Ni}^{+2}, \mathrm{Zn}^{+2}, \mathrm{Cd}^{+2}\right.$ and $\left.\mathrm{Hg}^{+2}\right)$

\section{References}

[1]. Sharma.V.,Pivinica. Worms D.,Chem,Rev,99,2545-2560,(1999).

[2]. Hassan H.M.,S.A.M. and Shedid M.S. shaheen, synthesis and characterization of some heterocyclic derivatives of valine as ant micro biologists , world journal of chemistry 6(1),1-7(2011)

[3]. 3-wang M.Z. ,Meng Z.X., Liu B.L, Zhang C.L. and Wang X.Y.,Inorganic chemistry .comm, 8,368-371,(2005).

[4]. Biot ,Christophe .Pardines ,Bruno ,sergeant,Marie -Helene .Gut.Jiri.Rosenbal philips,J.CHibale,Ketty,Bio org.med.chem.lett,17,6434-6438,(2007). 
[5]. Nair P.C. ,Sobbia M.E.,Eur .J.Met. chem.,43,293-299,(2008).

[6]. Ranjana S.,Shalini J. and Agrawal A. K. ",synthesis and structural studies of complexes of N-salicylidine amino acids (glycine, leucine with salicyldehyde) derived Schiff base with some bivalent transition metal ions ",International Journal of chem.,tech research, vol(2), No(1),728-732, (2010).

[7]. 7-R.Selwin,Joseyphne ,M. and Aivassn Karan Nair," synthesis ,characterization and biological studies of some Co(II),Ni(II) and $\mathrm{Cu}(\mathrm{II})$ complexes derived from indolecarboxaldehye and glycine as Schiff base ligand "Arabian journal of chemistry ,(3), 195204,(2011).

[8]. 8- Dhafir M. Husain al-mudhafar and Adil M.A, "synthesis ,characterization and biological activity of new amino acid derivatives containing selenium " international journal of apolitical science and technology, vol(2),No(4),83-89,(2012).

[9]. 9- Kabbani A. T.,H. Ramadan, Hammuud H. H.,Hanuom A.M. G. , and MouneimneY.,"synthesis of some metal complexes of $\mathrm{N}[($ benzoyl amino)-thioxomethyl] amino acid (HL)" ,Journal of the university of chemical technology and metallurgy, 40(4), 339344,(2005).

[10]. 10-Garey F. A.,"organic chemistry" , $6^{\text {th }}$ ed, the M C Graw-Hill companies ,Inc.,new York,pp,767,(2005).

[11]. 11- Silverstein Bassler R. M.G.C. and MovrllT.C.,"spectroscopic identification of organic compound" ${ }^{\text {th }}$ ed ,wily . New York,(1981).

[12]. 12- Marah J., "advanced organic chemistry " $4^{\text {th }}$ ed ,J.Wiley and sons, New York,(1991).

[13]. 13-Nakamoto K., "Infrared spectra of Inorganic and coordination compounds " $4^{\text {th }}$,John wily and Sons, New York,(1996) .

[14]. 14- Sadiaa M. Al-Hashimi , Sarhan B. M. and Salman A. W. "synthesis and characterization of complexes of N-acetyl -Detryptophan with some metal ions ", Iraq J.chem.28,pp1-11,(2002).

[15]. 15-Abdul sattar Z. K.,M.S.C. thesis University of Al-anbar,( 2013).

[16]. 16- Dyer ,R.J. "Application of absorption spectroscopy of organic comounds" prentice -Hall Inc. Englewood cliffs,N.J. London,(1996).

[17]. 17- Sadia M. Al-Hashimi, sarhan B.M. and A.J. Jarad, "synthesis and characterization complexes of 2 -thiotolyurea with metal salts "Journal of education ,No.6,pp543-553,(2011).

[18]. 18- Lever A.B.P.,"Inorganic electronic spectroscopy "Elsevier publishing company Amsterdam, London, New York , (1968).

[19]. 19- Sahan B.M. Himdan T.A. and EnassJ.W."synthesis and characterization of complexes of [N,N-Bis(2-hydroxyethyl)glycine with some metal salts ",Journal of college of education,(21),(1),pp269-283,(2012).

[20]. 20- Wisam K.Hamad,"synthesis and characterization of some suhphonic acid derivatives with some metal salts M.S.C.,thesis University of Al-anbar,(2012).

[21]. 21- Marcotrigiano G.,Menabue L. and pellami,G.C.J., Inorg.Nucl.chem.,vol(39),pp1897-1901,(1971).

[22]. 23- DoglasS.,DonaldW.,Holler F. and Grouchs,"Fundamemental of analytical chemistry "8 ${ }^{\text {th }}$ ed ,saunders college ,New York ,(2004).

Table (1) physical properties for free ligand and it's complexes

\begin{tabular}{|c|c|c|c|c|c|c|}
\hline Complex & M. wt. & Color & M.P. or dec. $C^{0}$ & $\begin{array}{l}\text { M\% calculation } \\
\text { (found) }\end{array}$ & $\begin{array}{c}\text { molar } \\
\text { conductivity } \\
\mathrm{Ohm}^{-1} \mathrm{~cm}^{2} \mathrm{~mol}^{-1} \\
\text { in DMSO }\end{array}$ & $\begin{array}{c}\mu \text { eff } \\
\text { (B.M) }\end{array}$ \\
\hline (cbv) & 314.5 & yellow & 155 & - & 3 & - \\
\hline $\mathrm{Mn}(\mathrm{cbv})_{2}$ & 683.94 & yellow & 183 & $\begin{array}{c}8.05 \\
(8.65)\end{array}$ & 8 & 5.91 \\
\hline $\mathrm{Fe}(\mathrm{cbv})_{2}$ & 684.85 & red & 209 & $\begin{array}{c}8.17 \\
(8.81) \\
\end{array}$ & 10 & 5.32 \\
\hline $\mathrm{Co}(\mathrm{cbv})_{2}$ & 687.93 & green & 174 & $\begin{array}{c}8.56 \\
(8.04)\end{array}$ & 12 & 4.85 \\
\hline $\mathrm{Ni}(\mathrm{cbv})_{2}$ & 687.71 & brown & 163 & $\begin{array}{c}8.54 \\
(8.78)\end{array}$ & 11 & 2.88 \\
\hline $\mathrm{Cu}(\mathrm{cbv})_{2}$ & 692.54 & green & 167 & $\begin{array}{c}9.20 \\
(10.89)\end{array}$ & 20 & 1.73 \\
\hline $\mathrm{Zn}(\mathrm{cbv})_{2}$ & 694.37 & white & 219dec. & $\begin{array}{c}9.44 \\
(9.84) \\
\end{array}$ & 15 & 0 \\
\hline $\mathrm{Cd}(\mathrm{cbv})_{2}$ & 741.4 & white & 160 & $\begin{array}{c}15.20 \\
(15.29) \\
\end{array}$ & 17 & 0 \\
\hline $\mathrm{Hg}(\mathrm{cbv})_{2}$ & 829.6 & deep green & 178 & $\begin{array}{c}24.23 \\
(23.89)\end{array}$ & 13 & 0 \\
\hline
\end{tabular}


Synthesis and Characterization of new metals complexes of [N-(4-chlorobenzoylamino)-

Table(2)the characteristic infrared band for free ligand and it's complexes

\begin{tabular}{|c|c|c|c|c|}
\hline Complex & $\lambda(\mathrm{nm})$ & $\mathrm{cm}^{-1}$ wave number & $\epsilon_{\max } \cdot \mathrm{L} \cdot \mathrm{mol}^{-1} \cdot \mathrm{cm}^{-1}$ & assignment \\
\hline cbv(ligand) & $\begin{array}{l}279 \\
494\end{array}$ & $\begin{array}{l}35842 \\
20242\end{array}$ & $\begin{array}{c}1836 \\
30\end{array}$ & $\begin{array}{l}\pi \rightarrow \pi^{*} \\
\mathrm{n} \rightarrow \pi^{*}\end{array}$ \\
\hline$\left[\mathrm{Mn}(\mathrm{cbv})_{2}\right]$ & $\begin{array}{l}268 \\
642 \\
845\end{array}$ & $\begin{array}{l}37313 \\
15576 \\
11834\end{array}$ & $\begin{array}{l}708 \\
32 \\
19\end{array}$ & $\begin{array}{l}\text { (C.T.) } \\
{ }^{6} \mathrm{~A}_{1} \rightarrow{ }^{2} \mathrm{~T}_{2}(\mathrm{G}) \\
{ }^{6} \mathrm{~A}_{1} \mathrm{~g} \rightarrow{ }^{4} \mathrm{~T}_{1}(\mathrm{G})\end{array}$ \\
\hline$\left[\mathrm{Fe}(\mathrm{cbv})_{2}\right]$ & $\begin{array}{l}294 \\
863\end{array}$ & $\begin{array}{l}34013 \\
11587\end{array}$ & $\begin{array}{c}1916 \\
19\end{array}$ & $\begin{array}{l}\text { (C.T.) } \\
{ }^{5} \mathrm{E} \rightarrow{ }^{5} \mathrm{~T}_{2}\end{array}$ \\
\hline$\left[\mathrm{Co}(\mathrm{cbv})_{2}\right]$ & $\begin{array}{l}300 \\
\\
664 \\
845 \\
\end{array}$ & $\begin{array}{l}33333 \\
15060 \\
11834 \\
\end{array}$ & $\begin{array}{c}2196 \\
70 \\
43 \\
\end{array}$ & $\begin{array}{l}{ }^{4} \mathrm{~A}_{2} \stackrel{V_{3}}{\rightarrow} \mathrm{T}_{1(\mathrm{p})} \\
\text { Mix with (C.T.) } \\
{ }^{4} \mathrm{~A}_{2} \stackrel{V_{2}}{\rightarrow} \mathrm{T}_{1(\mathrm{f})} \\
{ }^{4} \mathrm{~A}_{2} \stackrel{V_{1}}{\rightarrow} \mathrm{T}_{2(\mathrm{f})}\end{array}$ \\
\hline$\left[\mathrm{Ni}(\mathrm{cbv})_{2}\right]$ & $\begin{array}{l}270 \\
304 \\
670 \\
886\end{array}$ & $\begin{array}{l}37037 \\
32894 \\
14925 \\
11286\end{array}$ & $\begin{array}{c}1154 \\
1118 \\
56 \\
20\end{array}$ & $\begin{array}{l}\text { (C.T.) } \\
{ }^{3} \mathrm{~T}_{1(\mathrm{f})} \stackrel{V_{3}}{\rightarrow}{ }^{3} \mathrm{~T}_{1(\mathrm{p})} \\
{ }^{3} \mathrm{~T}_{1(\mathrm{f})} \stackrel{V_{2}}{\rightarrow} \mathrm{A}_{2(\mathrm{f})} \\
{ }^{3} \mathrm{~T}_{1(\mathrm{f})}{\stackrel{V_{1}}{\rightarrow}}^{3} \mathrm{~T}_{2(\mathrm{f})}\end{array}$ \\
\hline$\left[\mathrm{Cu}(\mathrm{cbv})_{2}\right]$ & $\begin{array}{l}274 \\
859\end{array}$ & $\begin{array}{l}36496 \\
11641\end{array}$ & $\begin{array}{c}1616 \\
50\end{array}$ & $\begin{array}{l}\text { (C.T) } \\
{ }^{2} \mathrm{~B}_{1} \mathrm{~g}_{\rightarrow}{ }^{2} \mathrm{~A}_{1} \mathrm{~g}\end{array}$ \\
\hline$\left[\mathrm{Zn}(\mathrm{cbv})_{2}\right]$ & 297 & 33670 & 2012 & (C. T.) \\
\hline$\left[\mathrm{Cd}(\mathrm{cbv})_{2}\right]$ & 294 & 34012 & 1916 & (C. T.) \\
\hline$\left[\mathrm{Hg}(\mathrm{cbv})_{2}\right]$ & 268 & 37313 & 1120 & (C.T.) \\
\hline
\end{tabular}

Table (3) Uv-visible absorption for the ligand (cbv) and it's complexes in DMSO $10^{-3} \mathrm{M}$
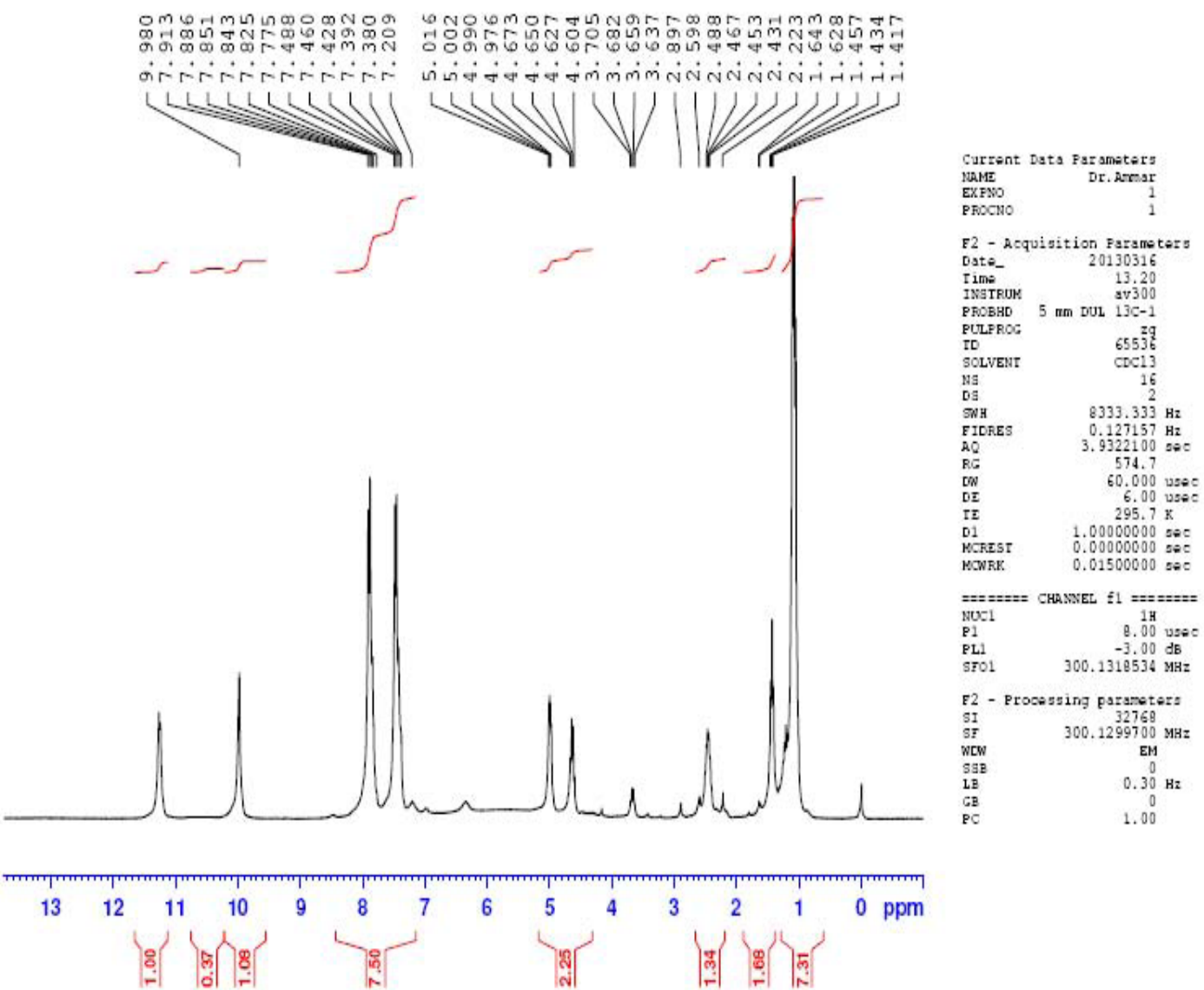

$\operatorname{Fig}(1){ }^{1} \mathrm{H}$ NMR of (cbv) 

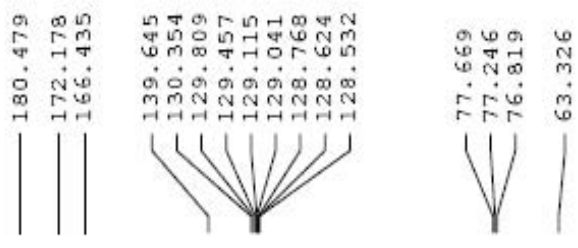

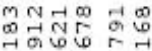

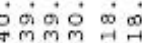
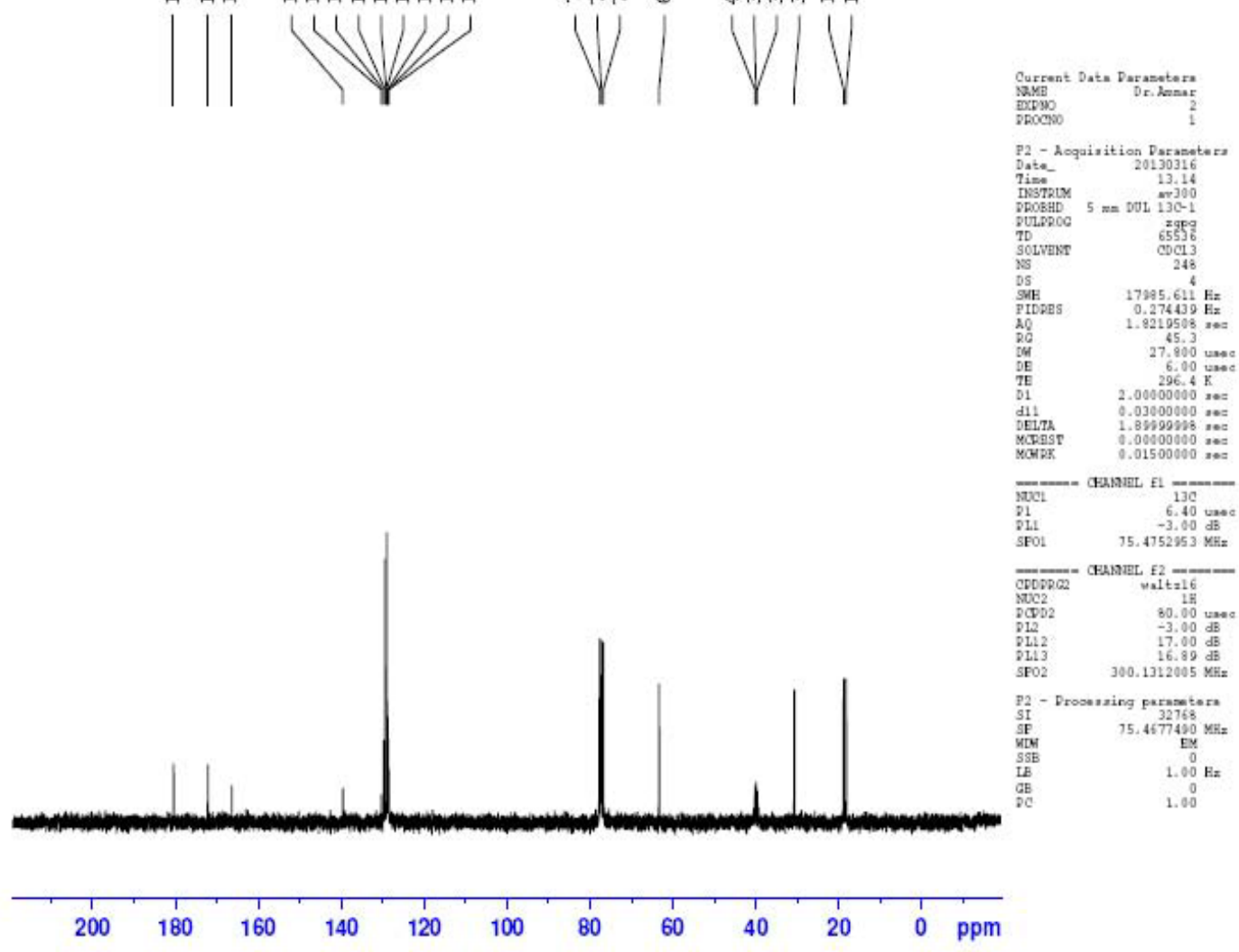

$\operatorname{Fig}(2){ }^{13} \mathrm{C}$ NMR of $(\mathrm{cbv})$

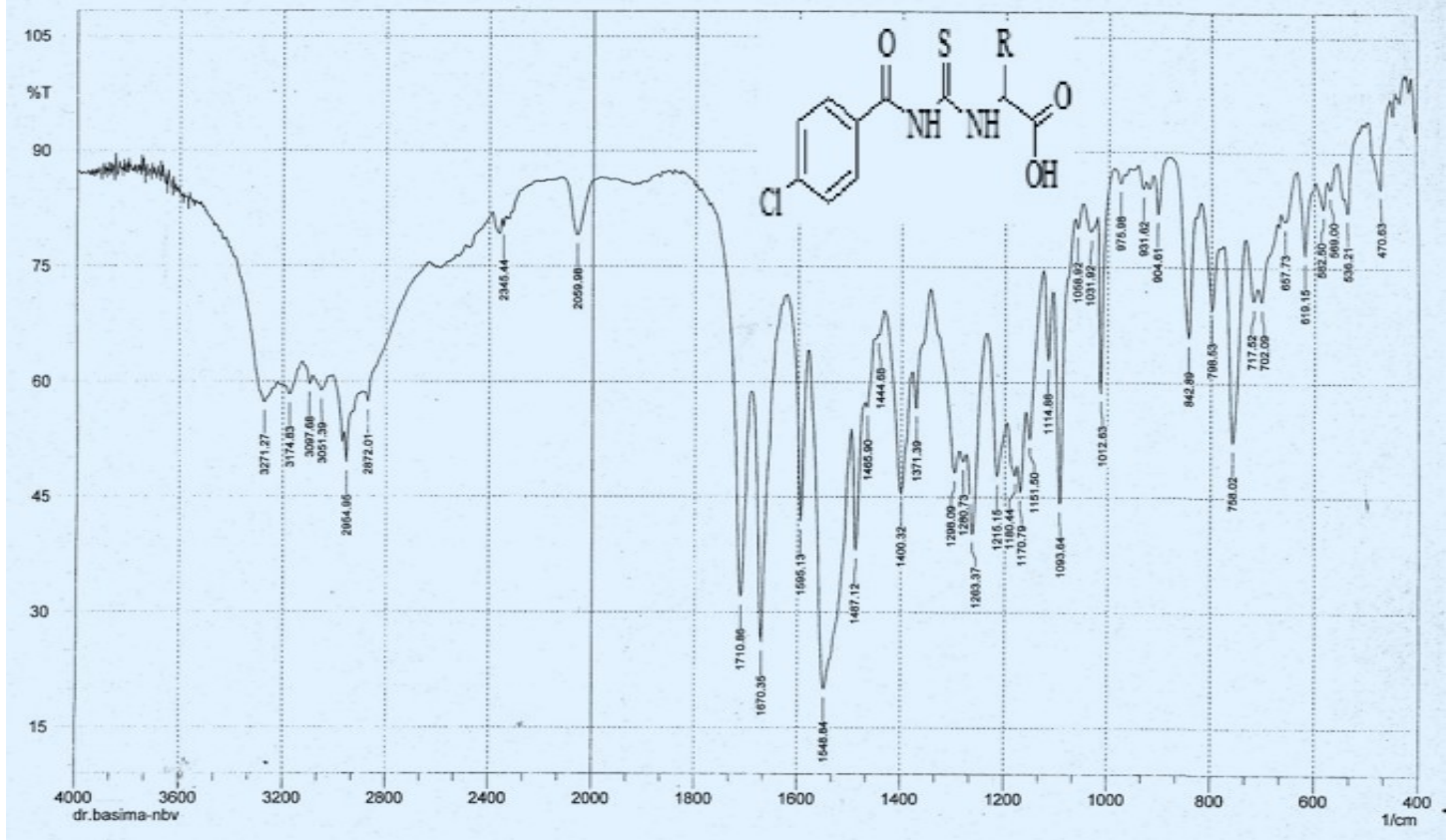

Fig (3)Ft -IR spectrum of the free ligand (cbv) 


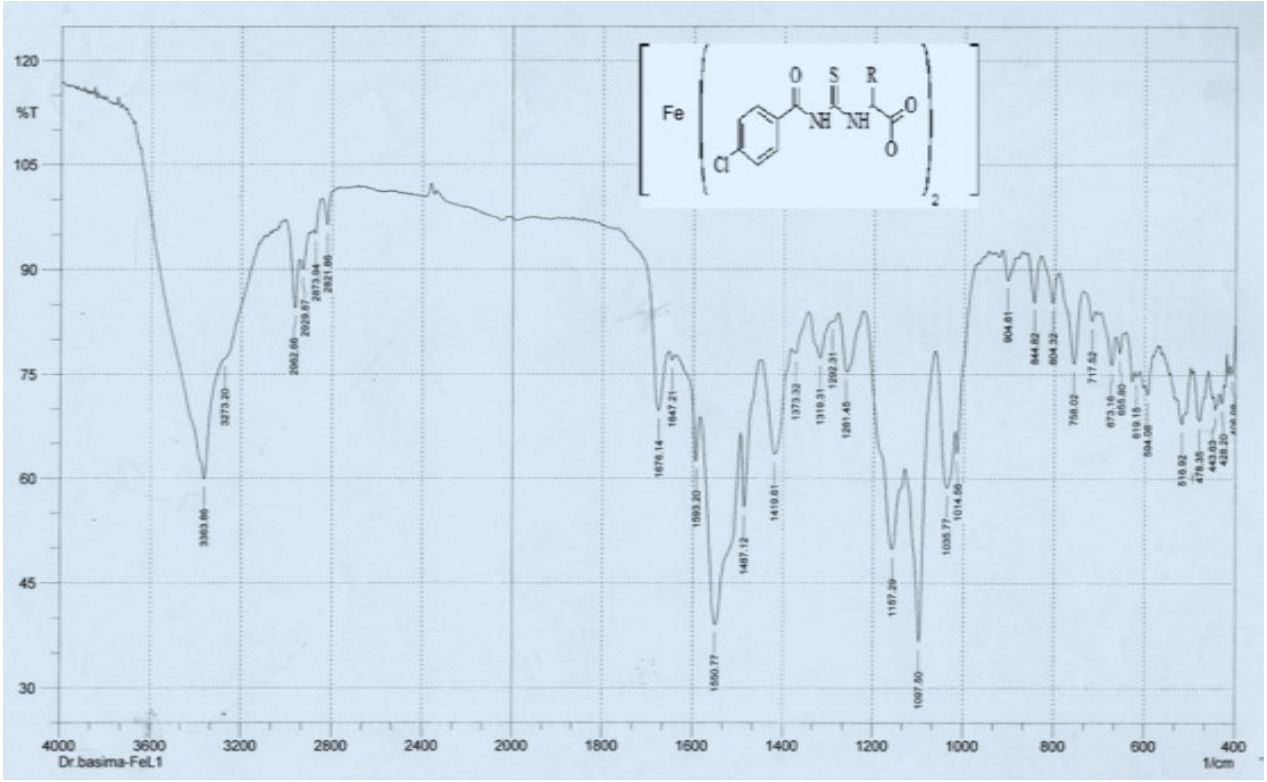

Fig (4) FT-IR spectra of (Fe) complex

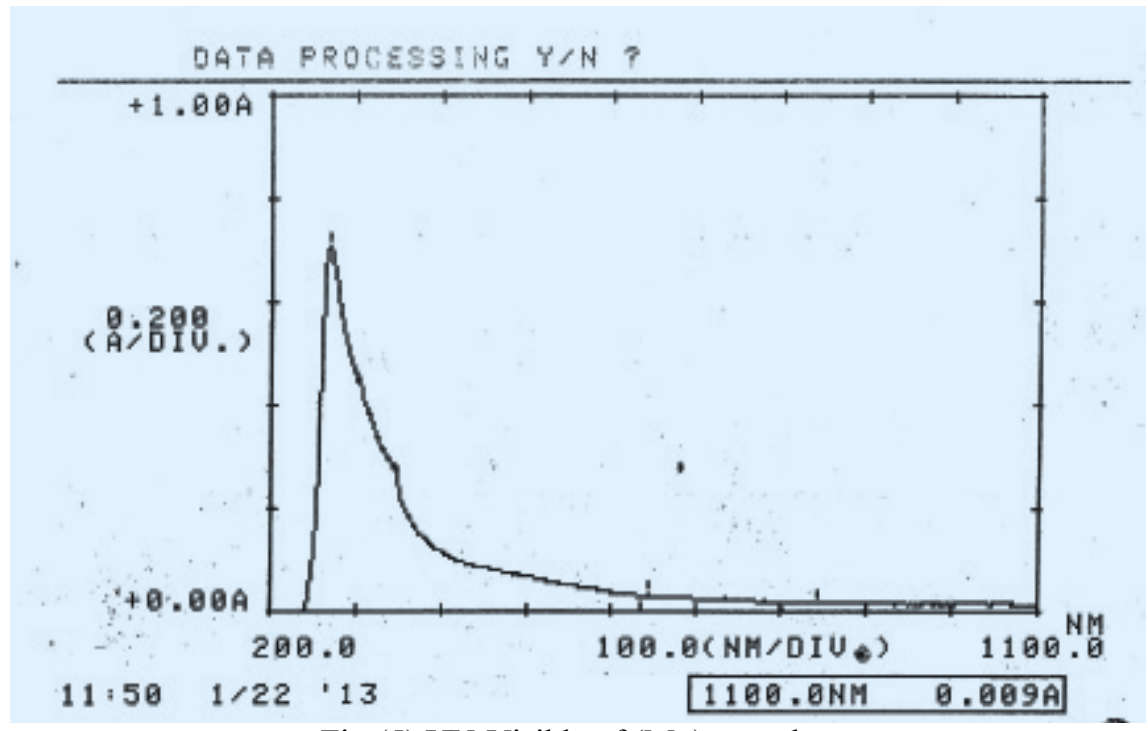

Fig (5) UV-Visible of (Mn) complex 